\title{
Firms' Innovation in Waste Management and Land Fertilizers within the Triad
}

\author{
Concetto Paolo Vinci ${ }^{1} \&$ Luigi Aldieri ${ }^{1}$ \\ ${ }^{1}$ Department of Economic and Statistical Sciences, University of Salerno, Italy \\ Correspondence: Concetto Paolo Vinci, Department of Economic and Statistical Sciences, University of Salerno, \\ Italy. E-mail: cpvinci@unisa.it
}

Received: May 23, 2017

Accepted: June 26, 2017

Online Published: July 18, 2017

doi:10.5539/ijbm.v12n8p120

URL: https://doi.org/10.5539/ijbm.v12n8p120

\begin{abstract}
In this paper we investigate agricultural innovation in three economic areas: the USA, Japan and Europe, taking into account simultaneously both the spatial and technological dimensions.

In particular, we introduce a theoretical framework and an empirical analysis based upon a dataset composed of worldwide R\&D-intensive firms to discuss the role of spillover components in the waste management efficiency at firm level. The technological relatedness between the firms is computed through an original Mahalanobis Environmental industry weight matrix, based on the construction of technological vectors for each firm. Methodologically, from one hand, we explore the extent to which knowledge spillovers are important through spatial analysis procedure and from the other hand, we measure the effects of technology spillovers on firms' productivity through econometric methods to handle heterogeneity and endogenous explanatory variables. The findings show a positive impact of Jacobian $R \& D$ spillovers on firms' productivity and environmental performance and this result can be relevant repercussions in terms of policy implications.
\end{abstract}

Keywords: agriculture innovation, technology spillovers, spatial analysis

JEL codes: O32; O33; Q5.

\section{Introduction}

Agricultural sector assumes a strategic role for innovation, productivity, profitability and competitiveness (Läpple et al. 2016; OECD, 2013). However, we may identify considerable differences in agricultural innovation across countries, as discussed in Spielman and Birner (2008); OECD (2013); Läpple et al. (2016). This result might be explained through different policies, institutional settings and infrastructural environments of knowledge transfer systems between countries. Literature evidences more factors affecting agricultural innovation. Läpple et al. (2015) find that innovative performance is influenced by demographic structures, while according to Rand et al. (2009), geographic distance can have an impact on innovation process. It is recognized in the literature the role of spatial concentration in the knowledge flows among economic units (Case, 1992; Läpple and Kelley, 2015; Läpple et al., 2016). However, there are mixed theories in relation to proximity and innovation. Indeed, Jaffe et al. (1993) and Audretsch and Feldman (1996) find that firms located near knowledge centers display a higher innovation level than more distant firms, while Breschi (2000) stresses that the geographical concentration of innovative processes can differ strikingly across technology sectors. There are few studies that investigate innovation in the agricultural sector taking into account simultaneously both the spatial and technological dimensions. This article aims to overcome this deficit by discussing the role of knowledge spillovers in spatial context and on the basis of environmental technology proximity.

The paper is structured as follows: the next section provides the spatial analysis of waste and land innovation of firms located within the Triad. A theoretical framework about knowledge externalities is introduced, followed by Data and empirical Methods section. Thus, discussion of results is presented. Finally, the paper ends with some concluding remarks.

\section{Agriculture Innovation and Spatial Analysis within the Triad}

In table 1, we show land use percentages for countries considered in our analysis. As discussed in the previous section, different efficiency levels can be observed. 
In order to assess agricultural innovation and explore its spatial distribution, we use particular spatial econometric tools (Pisati, 2008; Crow, 2015; Kondo, 2015 and 2016).

As in Marin and Lotti (2016), environmental innovations are identified through appropriate indicators on patent data, according to their technological class (Note 1). In Table 2, we report those patents with IPC code belonging to the groups selected by the OECD or the World Intellectual Property Organization (WIPO).

Table 1. Land use by economic area

\begin{tabular}{lllll}
\hline & Agricultural land & Arable land & Permanent crops & Permanent posture \\
\hline the USA & $44.50 \%$ & $16.80 \%$ & $0.30 \%$ & $27.40 \%$ \\
Japan & $12.50 \%$ & $11.70 \%$ & $0.80 \%$ & $0 \%$ \\
Europe: & & & & $13.30 \%$ \\
Germany & $48 \%$ & $34.10 \%$ & $0.60 \%$ & $17.50 \%$ \\
France & $52.70 \%$ & $33.40 \%$ & $1.80 \%$ & $15.70 \%$ \\
Italy & $47.10 \%$ & $22.80 \%$ & $8.60 \%$ & $45.70 \%$ \\
UK & $71 \%$ & $25.10 \%$ & $0.20 \%$ & $24.20 \%$ \\
the Netherlands & $55.10 \%$ & $29.80 \%$ & $1.10 \%$ & $0.10 \%$ \\
Finland & $7.50 \%$ & $7.40 \%$ & $0 \%$ & $1.10 \%$ \\
Sweden & $7.50 \%$ & $6.40 \%$ & $0 \%$ & \\
\hline
\end{tabular}

Source: The CIA World Factbook Land Use, 2017.

Table 2. Environmental patent classes

\begin{tabular}{ll}
\hline Macro category & IPC \\
\hline & E01H, B65F \\
& A23K, A43B, B03B, B22F, B29B, B30B, B62D, B65H, B65D, C03B, C03C, \\
& C04B, C08J, C09K, C10M, C22B, D01G, D21B, D21C, D21H, H01B, H01J, \\
& H01M \\
Waste management & B09B, C10G, A61L \\
and Land fertilizers & F03G, B60K, B60L, B09B, B65F \\
& A61L, A62D, B03B, B09C, D21B \\
& F23G \\
& A43B, B22F, C04B, C05F, C08J, C09K, C11B, C14C, C21B, C25C, D21F, B29B, \\
& B62D, C08J, C10G, C10L, C22B, D01G, D21C, H01J, H01M \\
\hline
\end{tabular}

First, we test for the existence of spatial autocorrelation in waste and land innovation, which characterizes the degree to which a region and its neighboring regions are mutually correlated. Moran's I test has the following form (Moran, 1950; Anselin, 1995): $I=\frac{z \prime W z}{z \prime z}$, where $\mathrm{z}$ is an $\mathrm{N}-$ vector of standardized waste and land fertilizers patents, $\mathrm{W}$ is an $\mathrm{N} \times \mathrm{N}$ row-standardized spatial weight matrix (Note 2) and $\mathrm{N}$ is the number of observations. This study also presents Moran scatterplots, which depict how the geographical units depend on each other (Anselin, 1995).

As we may observe in Tables $3-5$, the positive value of Moran-I indicates positive spatial autocorrelation across the regions of each economic area: that is, regions neighboring a region with high waste and land fertilizers patents also show high agricultural innovation rates. 


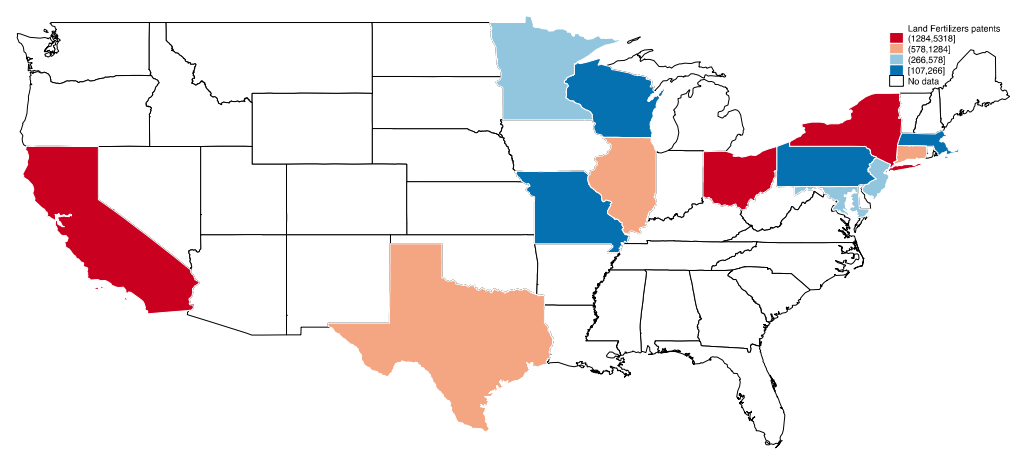

Figure 1. Waste and land fertilizers patents in the USA

Figures $1-3$ explore hot/cold spot analysis by economic areas.

In Figure 1, where the USA country is clustered into 51 states, we may observe that New York and California exhibit the hot spots, while Massachusetts, Missouri and Wisconsin display the cold spots.

Table 3. Moran scatterplot for the USA

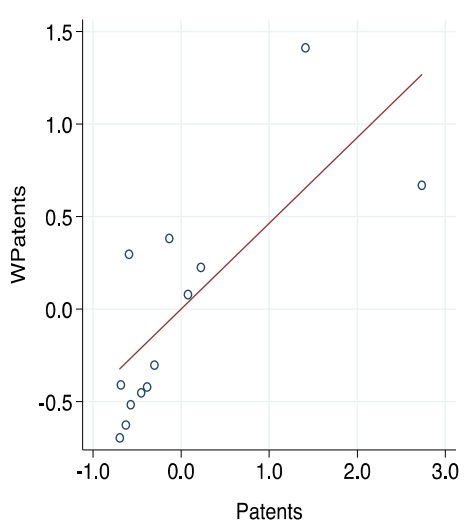

Note: Moran-I test: 0.463 , p-value: 0.00

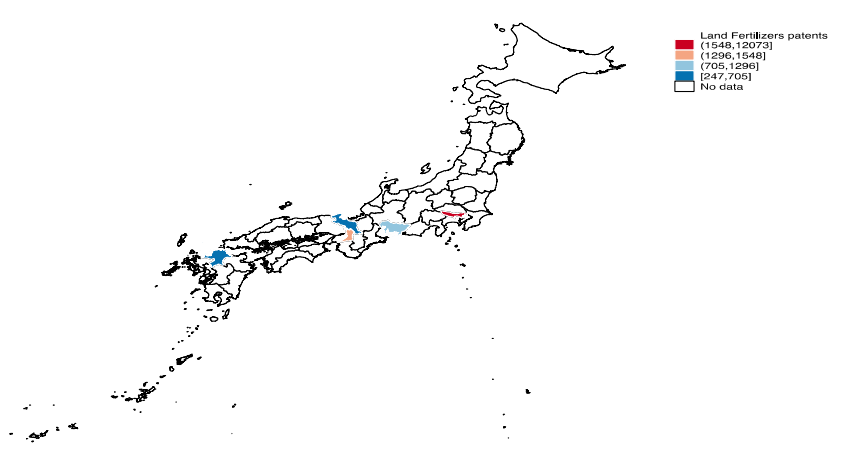

Figure 2. Waste and land fertilizers patents in Japan

In Figure 2, where Japan country is clustered into 47 prefectures, we observe that Tokyo exhibits hot spots, while Fukuoka displays cold spots. 
Table 4. Moran scatterplot for Japan

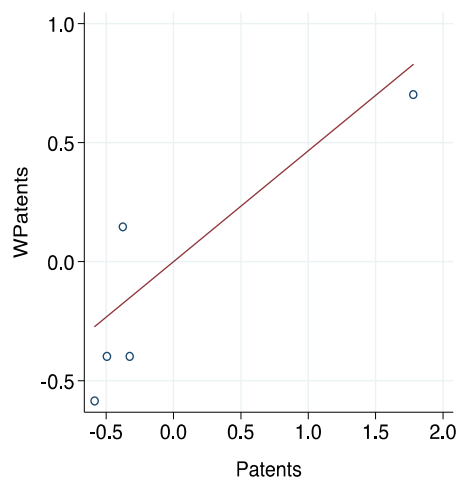

Note: Moran-I test: 0.466, p-value: 0.048 .

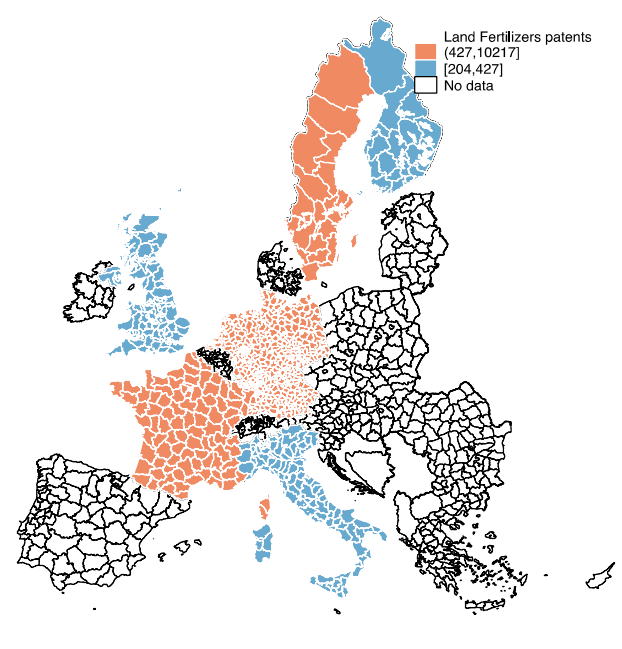

$\therefore \circ D^{5}$

Figure 3. Waste and Land Fertilizers patents in Europe

In Figure 3, where Europe is clustered into 42 countries, we observe that Germany exhibits hot spots, while Finland displays cold spots.

Table 5. Moran Scatterplot for Europe

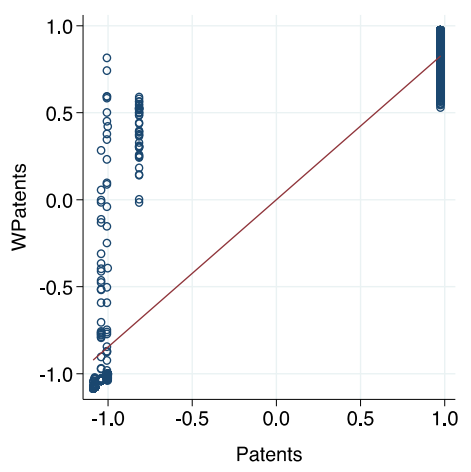

Note: Moran-I test: 0.847 , p-value: 0.000 . 


\section{Theoretical Framework}

In this section, as in Aldieri, Kotsemir and Vinci (2017) we present a simple theoretical model, useful for our econometric analysis. We will refer to a multi-sector economy where production may pursue two different procedures: The standard, and a second one where production combines varieties of types of green energy concerning waste management and land fertilizers with physical, human and knowledge capital. The number of varieties in each sector is determined endogenously, and investment in these technology classes is assumed to depend on rational agents' decisions (Bretschger et al., 2017). In each sector the final output $Y$, depends on production of two different techniques: green $\left(Y_{g}\right)$ and not $\left(Y_{N}\right)$ may be taken as:

$$
\begin{gathered}
Y=Y\left(Y_{g}, Y_{N}\right) \\
Y_{g}=Y_{g}\left(C_{g}, K_{g}, H_{g}\right) \\
Y_{N}=Y_{N}\left(C_{N}, K_{N}, H_{N}\right) \\
K_{N}=K_{N}\left(K_{g}\right) \\
K_{h}=K_{h}\left(B_{h} ; B_{h}^{R}\right) \\
B_{g}=B_{g}(\chi) \\
B_{g}^{R}=B_{g}^{R}\left(\chi^{R}\right) \\
\chi=\sum_{i=1}^{n} a_{i} x_{i}
\end{gathered}
$$

With: $0<a_{i}<1$

$$
\chi^{R}=\sum_{j=1}^{n_{R}} a_{j} x_{j}^{R}
$$

With: $0<a_{j}<1$.

Parameters $C_{g}$ and $C_{N}, H_{g}$ and $H_{N}$ stand respectively for physical and human capital, green and not, the innovation impact on the technology are embodied by the impact of knowledge capital levels denoted $K_{g}$ and $K_{N}$, and patents denoted $B_{g}$, depends on $\chi$, a variable capturing the effects of different waste management and land fertilizers technological fields $x_{i}$. At last $B_{g}^{R}, \chi^{R}$ measure respectively for patents, and the variable catching the above green special effects from abroad. We may easily derive that:

$$
Y=Y\left(Y_{N}\left\{C_{N}, H_{N}, K_{N}\left[K_{g}\left(B_{g}\left(\sum_{i=1}^{n} a_{i} x_{i}\right), B_{g}^{R}\left(\sum_{j=1}^{n_{R}} a_{j} x_{j}^{R}\right)\right)\right]\right\}, Y_{g}\left\{C_{g}, H_{g}, K_{g}\left(B_{g}\left(\sum_{i=1}^{n} a_{i} x_{i}\right), B_{g}^{R}\left(\sum_{j=1}^{n_{R}} a_{j} x_{j}^{R}\right)\right)\right\}\right)(10)
$$

The short run impacts of innovation respectively on $Y_{g}$ and $Y$ may written as:

$$
\begin{gathered}
d Y_{g}=\frac{\partial Y_{g}}{\partial C_{g}} d C_{g}+\frac{\partial Y_{g}}{\partial H_{g}} d H_{g}+\frac{\partial Y_{g}}{\partial K_{g}}\left\{\frac{\partial K_{g}^{g}}{\partial B_{g}} \frac{\partial B_{g}}{\partial \chi}\left[\sum_{i=1}^{n} a_{i} d x_{i}\right]+\frac{\partial K_{g}}{\partial B_{g}^{R}} \frac{\partial B_{g}^{R}}{\partial \chi^{R}}\left[\sum_{j=1}^{n_{R}} a_{j} d x_{j}^{R}\right]\right\} \\
d Y=\frac{\partial Y}{\partial Y_{g}}\left\{\frac{\partial Y_{g}}{\partial c_{g}} d C_{g}+\frac{\partial Y_{g}}{\partial H_{g}} d H_{g}+\frac{\partial Y_{g}}{\partial K_{g}}\left\{\frac{\partial K_{g}}{\partial B_{g}} \frac{\partial B_{g}}{\partial \chi}\left[\sum_{i=1}^{n} a_{i} d x_{i}\right]+\frac{\partial K_{g}}{\partial B_{g}^{R}} \frac{\partial B_{g}^{R}}{\partial \chi^{R}}\left[\sum_{j=1}^{n_{R}} a_{j} d x_{j}^{R}\right]\right\}\right\}+\frac{\partial y}{\partial Y_{N}}\left\{\frac{\partial Y_{N}}{\partial C_{N}} d C_{N}+\right. \\
\left.\frac{\partial Y_{N}}{\partial H_{N}} d H_{N}+\frac{\partial Y_{N}}{\partial K_{N}} \frac{\partial K_{N}}{\partial K_{g}}\left\{\frac{\partial K_{W}}{\partial B_{W}} \frac{\partial B_{W}}{\partial \chi}\left[\sum_{i=1}^{n} a_{i} d x_{i}\right]+\frac{\partial K_{g}}{\partial B_{g}^{R}} \frac{\partial B_{g}^{R}}{\partial \chi^{R}}\left[\sum_{j=1}^{n_{R}} a_{j} d x_{j}^{R}\right]\right\}\right\}
\end{gathered}
$$

Inspection of eqs. (11) and (12) yields the following research hypothesis:

[H]: The effect of spillovers due to diversified green technology fields concerning waste management and land fertilizers (Jacobian externalities) on firms' productivity is positive 


\section{Data and Methodology}

We derive data from OECD, REGPAT database, February 2016 (Note 3). This dataset covers firms' patent applications to the European Patent Office (EPO) including patents published up to December 2015. We match the name of the same 240 firms to applicant's name from European Commission (2013), as in Aldieri (2013). We follow two steps: patents are assigned to firms on the basis of their generic name; this procedure is repeated for each firm of our sample (Aldieri, 2013). The third source of data is the World Input Output Database (WIOD), which is made up of four different accounts (World Tables, National Tables, Socio Economic Accounts and Environmental Accounts). For purposes of this paper, we use the Environmental Accounts providing $\mathrm{CO} 2$ emissions variable by country and by year.

To identify the impact of environmental spillovers on firms' productivity, we consider the following specification model:

$$
\ln Y_{i t}=\alpha_{i}+\lambda_{t}+\beta_{1} \ln L_{i t}+\beta_{2} \ln C_{i t}+\beta_{3} \ln K_{i t}+\gamma_{1} \ln M A R S_{i t}+\gamma_{2} \ln J S_{i t}+\varepsilon_{i t}
$$

Where $\ln =$ natural logarithm;

$Y_{i t}=$ Productivity measured by net sales for firm $i$ and year t;

$C_{i t}=$ physical capital stock for firm $i$ and year $t$;

$L_{i t}=$ number of employees for firm $i$ and year $t$;

$K_{i t}=\mathrm{R} \& \mathrm{D}$ capital stock of firm $i$ and year $t$;

$\alpha_{i}=$ firm's fixed effects;

$\lambda_{t}=$ set of time dummies;

$M A R S_{i t}=$ vector of Marshall, Arrow, Romer spillovers (or externalities from firms of the same technology sector) for firm $i$ and year $t$;

$J S_{i t}=$ vector of Jacobian spillovers (or externalities from firms of the different technology sector) for firm $i$ and year $t$;

$\beta, \gamma=$ vectors of parameters;

$\varepsilon_{i t}=$ disturbance term.

Moreover, in order to evaluate the environmental performance of knowledge spillovers, we estimate also another model with ratio between productivity and $\mathrm{CO} 2$ (SCO2) as dependent variable (Repetto, 1990) and regressors like in (13). In Table 6, we show the summary statistics of our sample. In particular, we consider both the environmental spillovers based on the Mahalanobis procedure (Aldieri, Kotsemir and Vinci, 2017) and the R\&D capital stock based on the perpetual inventory method (Griliches, 1979) with a 5\% initial growth rate and a 15\% depreciation rate.

Table 6. Summary statistics

\begin{tabular}{lll}
\hline Variable & Mean $^{\mathrm{a}}$ & Std. Dev. \\
\hline $\ln Y$ & 8.50 & 1.450 \\
$\operatorname{lnSCO} 2$ & 21.68 & 4.021 \\
$\ln C$ & 7.49 & 1.584 \\
$\operatorname{lnL}$ & 9.97 & 1.360 \\
$\operatorname{lnK}$ & 7.15 & 1.426 \\
$\ln \mathrm{MARS}$ & 0.96 & 1.641 \\
$\ln \mathrm{SS}$ & 1.117 & 1.913 \\
\hline
\end{tabular}

Note: a) 1837 observations;

\section{Results and Discussion}

To address both firms' unobserved heterogeneity and the weak exogeneity of the explanatory variables, we estimate equation (13) using a one-stage generalized method of moments (GMM)) (Note 4) estimator, which combines the standard set of equations in the first difference with suitably lagged levels as instruments (GMM in 
first differences), with an additional set of equations in levels with suitably lagged first differences as instruments. The validity of these additional instruments, which consist of first difference-lagged values of the regressors, can be tested through over-identification tests. The one-stage GMM (GMM SYS) estimator can lead to considerable improvements in terms of efficiency compared to the GMM in first differences (GMM FD).

In Table 7 and Table 8, we present the empirical estimates for the GMM-SYS estimator. In particular, we show the effects of specialized activities spillovers (MARS) and diversified technology fields spillovers (JS) on firms' productivity in Table 7 and environmental performance effects of spillovers in Table 8. We lag environmental spillover components by a year to reflect delayed response and also mitigate contemporaneous feedback effects.

Table 7. Productivity of Environmental Spillovers effects: GMM estimates

\begin{tabular}{|c|c|c|}
\hline \multicolumn{3}{|l|}{ Dependent variable: $\Delta \ln \mathrm{LS}_{\mathrm{t}}$} \\
\hline & Estimate & S.E. ${ }^{a}$ \\
\hline$\Delta \ln Y(t-1)$ & $0.86^{* * *}$ & $(0.054)$ \\
\hline$\Delta \operatorname{lnL}$ & $0.14 * * *$ & $(0.037)$ \\
\hline$\Delta \operatorname{lnC}$ & 0.01 & $(0.031)$ \\
\hline$\Delta \operatorname{lnK}$ & 0.04 & $(0.027)$ \\
\hline$\Delta \operatorname{lnMARS}(\mathrm{t}-1)$ & $-0.11^{* *}$ & $(0.050)$ \\
\hline$\Delta \operatorname{lnJS}(\mathrm{t}-1)$ & $0.97 * *$ & $(0.043)$ \\
\hline $\operatorname{AR}(1)^{c}$ test & $\mathrm{z}=-5.00$ & $\mathrm{p}>\mathrm{z}=0.000$ \\
\hline $\mathrm{AR}(2)$ test & $\mathrm{z}=0.29$ & $\mathrm{p}>\mathrm{z}=0.772$ \\
\hline Hansen $^{\mathrm{b}}: \chi^{2}(129)=145.73$ & & [0.149] \\
\hline
\end{tabular}

Notes: a: heteroskedastic-consistent standard errors; b: Hansen test of over-identifying restrictions, p-value in squared brackets; c: AR(1) and $\mathrm{AR}(2)$ are tests for first- and second-order serial correlation; ***, **, coefficient significant at the $1 \%, 5 \%$ level respectively. Country, time and industry dummies included. Endogenous variables are physical capital, labor, R\&D capital stock and spillovers. Instruments are lagged values (2-9) of all explanatory variables.

Table 8. Environmental Performance of Spillovers effects: GMM estimates

\begin{tabular}{lll}
\hline Dependent variable: $\Delta \ln \mathrm{LS}_{\mathrm{t}}$ & & \\
\hline & Estimate & S.E. $^{\mathrm{a}}$ \\
$\Delta \ln \mathrm{Y}(\mathrm{t}-1)$ & $0.84^{* * *}$ & $(0.044)$ \\
$\Delta \ln \mathrm{C}$ & $0.66^{* * *}$ & $(0.114)$ \\
$\Delta \operatorname{lnC}$ & -0.01 & $(0.090)$ \\
$\Delta \operatorname{lnK}$ & -0.10 & $(0.104)$ \\
$\Delta \operatorname{lnMARS}(\mathrm{t}-1)$ & $-0.37^{* * *}$ & $(0.152)$ \\
$\Delta \operatorname{lnJS}(\mathrm{t}-1)$ & $0.31^{* * *}$ & $(0.131)$ \\
$\operatorname{AR}(1)^{\mathrm{c}}$ test & $\mathrm{z}=-5.89$ & $\mathrm{p}>\mathrm{z}=0.000$ \\
$\operatorname{AR}(2)$ test & $\mathrm{z}=0.30$ & $\mathrm{p}>\mathrm{z}=0.768$ \\
$\operatorname{Hansen}^{\mathrm{b}}: \chi^{2}(169)=183.33$ & & {$[0.213]$} \\
\hline
\end{tabular}

Notes: a: heteroskedastic-consistent standard errors; b: Hansen test of over-identifying restrictions, p-value in squared brackets; c: AR(1) and $\mathrm{AR}(2)$ are tests for first- and second-order serial correlation; ***, **, coefficient significant at the $1 \%, 5 \%$ level respectively. Country, time and industry dummies included. Endogenous variables are physical capital, labor, R\&D capital stock and spillovers. Instruments are lagged values (2-9) of all explanatory variables. 
As the model is over-identified in the sense that there are more instruments than parameters to be estimated, the validity of the instruments can be tested by means of the Hansen test for over-identified restrictions. Considering the set of instruments used and the need to satisfy the orthogonality conditions, it helps to verify the null hypothesis of the joint validity of the instruments. The Hansen test is $X^{2}$ distributed under the null with ( $\left.\mathrm{p}-\mathrm{k}\right)$ degrees of freedom (where $p$ is the number of instruments and $k$ is the number of variables in the regression).

The model specification includes country, time, and industry dummies, which capture the impact of factors that change over time but not over the cross-sectional dimension of the sample. The results of the AR (1) and AR (2) tests are consistent with the assumption of no serial correlation in the residuals in levels and the Hansen tests do not reject the null hypothesis of valid instruments, indicating that the instruments are not correlated with the error term.

The interesting results are relative to causal effects of environmental spillovers on productivity and environmental performance. In particular, specialized environmental technology fields spillovers (MARS) have a negative impact, while the diversified activities portfolio (Jacobian spillovers) has a positive one, by confirming the theoretical predictions. This finding is extremely important for policy implications. In addition to economic incentives to favor the complementarity between dirty and environmental activities to balance competitiveness and sustainability, also the integration between the waste management and land fertilizers technology fields is crucial for a full sustainable achievement of firms.

\section{Conclusions}

Since there are few studies that investigate innovation in the agricultural sector taking into account simultaneously both the spatial and technological dimensions, the aim of this article is to overcome this deficit by discussing the role of knowledge spillovers in spatial context and on the basis of environmental technology proximity.

From one hand, we demonstrate that there is significant positive spatial autocorrelation across the regions of each economic area: that is, regions neighboring a region with high waste and land fertilizers patents also show high agricultural innovation rates.

In particular, hot/cold spot analysis evidences heterogeneous results in knowledge spillovers by economic areas.

From another hand, once we verify that spatial concentration matters for spillovers, we test for the effects of spillovers in technological sectors perspective. In particular, specialized environmental technology fields spillovers (MARS) have a negative impact, while the diversified activities portfolio (Jacobian spillovers) has a positive one, by confirming the theoretical predictions.

However, further analysis is needed. In particular, research could usefully focus on factors that determine heterogeneity in knowledge spillovers effects in spatial context and on the basis of technology sectors. Moreover, further empirical research should investigate the robustness of results also for other environmental fields, such as water or energy resources (Aldieri \& Vinci, 2017).

\section{References}

Aldieri, L. (2013). Knowledge technological proximity: evidence from US and European patents. Economics of Innovation and New Technology, 22, 807-819. http://dx.doi.org/10.1080/10438599.2013.788838

Aldieri, L., Kotsemir, M., \& Vinci, C. P. (2017). Jacobian spillovers in Environmental Technological Proximity: The role of Mahalanobis index on European Patents within the Triad. MPRA Working Paper N. 77274.

Aldieri, L., \& Vinci, C. P. (2017). The Role of Technology Spillovers in the Process of Water Pollution Abatement for Large International Firms. Sustainability, 9(5), 868, http://dx.doi.org/10.3390/su9050868

Anselin, L. (1995). Local Indicators of spatial association-LISA. Geographical Analysis, 27, 93-115. http://dx.doi.org/10.1111/j.1538-4632.1995.tb00338.x

Arellano, M., \& Bover, O. (1995). Another look at the instrumental-variable estimation of error-components models. Journal of Econometrics, 68, 29-52. http://dx.doi.org/10.1016/0304-4076(94)01642-D

Audretsch, D., \& Feldman, M., (1996). R\&D Spillovers and the geography of innovation and production. American Economic Review, 86, 630-640.

Blundell, R. W., \& Bond, S. R. (1998). Initial conditions and moment restrictions in dynamic panel data models. Journal of Econometrics, 87, 115-143. http://dx.doi.org/10.1016/S0304-4076(98)00009-8

Bottazzi, L., \& Peri, G. (2003). Innovation and Spillovers in regions: Evidence from European patent data. European Economic Review, 47, 687-710. http://dx.doi.org/10.1016/S0014-2921(02)00307-0 
Breschi, S. (2000). The geography of innovation: A cross-sector analysis. Regional Studies, 34, 213-229. http://dx.doi.org/10.1080/00343400050015069

Bretschger, L.,. Lechthaler, F., R., \& Zhang, S., L. (2017). Knowledge diffusion, endogenous growth, and the costs of global climate policy. European Economic Review, (93), 47-72. http://dx.doi.org/10.1016/j.euroecorev.2016.11.012

Case, A. (1992). Neighbourhood influence and technological change. Regional Science and Urban Economics, 22, 491-508. http://dx.doi.org/10.1016/0166-0462(92)90041-X

Crow, K. (2015). SHP2DTA: Stata module to convert shape boundary files to Stata datasets. https://ideas.repec.org/c/boc/bocode/s456718.html

European Commission. (2013). The 2013 EU Industrial R\&D Investment Scoreboard, JRC Scientific and Technical Research series. Retrieved from http://iri.jrc.ec.europa.eu/scoreboard.html

Griliches, Z. (1979). Issues in assessing the contribution of R\&D to productivity growth. Bell Journal of Economics, 10, 92-116. http://dx.doi.org/10.2307/3003320

Jaffe, A. B., Tratjenberg, M., \& Henderson, M. (1993). Geographic localisation and knowledge spillovers as evidenced by patent citations. Quarterly Journal of Economics, 108, 577-598. http://dx.doi.org/10.2307/2118401

Kondo, K. (2015). SPGEN: Stata module to generate spatially lagged variables. Retrieved from http://econpapers.repec.org/software/boc/bocode/S458105.html

Kondo, K. (2016). Hot and cold spot analysis using Stata. Stata Journal, 16, 613-631.

Läpple, D., Renwick, A., Cullinan, J., \& Thorne, F. (2016). What drives innovation in the agricultural sector? A spatial analysis of knowledge spillovers. Land Use Policy, 56, 238-250. http://dx.doi.org/10.1016/j.landusepol.2016.04.032

Läpple, D., \& Kelley, H. (2015). Spatial dependence in the adoption of organic drystock farming in Ireland. European Review of Agricultural Economics, 42, 315-337. http://dx.doi.org/10.1093/erae/jbu024

Läpple, D., Renwick, A., \& Thorne, F. (2015). Measuring and understanding the drivers of agricultural innovation: evidence from Ireland. Food Policy, 51, 1-8. http://dx.doi.org/10.1016/jfoodpol.2014.11.003

Maraut, S., Dernis, H., Webb, C., Spiezia, V., \& Guellec, D. (2008). The OECD REGPAT Database: A Presentation. STI Working Paper 2008/2, OECD, Paris.

Marin, G., \& Lotti, F. (2016). Productivity effects of eco-innovations using data on eco-patents. Industrial and Corporate Change. http://dx.doi.org/10.193/icc/dtw014

Moran, P. A. P. (1950). Notes on continuous stochastic phenomena. Biometrika, 37(1/2), 17-23. http://dx.doi.org/10.1093/biomet/37.1-2.17

OECD. (2013). Agricultural Innovation Systems: A Framework for Analysing the Role of the Government. OECD Publishing. http://dx.doi.org/10.1787/ 9789264200593-en

Pisati, M. (2008). SPMAP: Stata module to visualize spatial data. Retrieved from https://ideas.repec.org/c/boc/bocode/s456812.html

Rand, S., Neri, T., \& Knickel, K., (2009). Socio-technical context, framework conditions and drivers of rural innovation processes. In: Knickel, K., Tisenkopf, T., Peter, S. (Eds.), Innovation Processes in Agriculture and Rural Development In-SIGHT (pp. 22-38).

Repetto, R. (1990). Environmental productivity and why it is so important. Challenge, 33(5), 33-38. http://dx.doi.org/10.1080/05775132.1990.11471458

Spielman, D., \& Birner, R. (2008). How Innovative Is Your Agriculture? Using Innovation Indicators and Benchmarks to Strengthen National Agricultural Innovation Systems Agriculture and Rural Development Discussion Paper 41. The World Bank.

The CIA World Factbook Land Use (2017). Retrieved from https://www.cia.gov/library/publications/the-world-factbook/

\section{Notes}

Note 1. http://www.oecd.org/env/consumption-innovation/indicator.htm 
Note 2. We assume that spatial spillovers exists only within a distance of $300 \mathrm{~km}$ (Bottazzi and Peri, 2003).

Note 3. See Maraut et al. (2008) for the methodology used for the construction of REGPAT. Please contact Helene. DERNIS@oecd.org to download REGPAT database.

Note 4. See Arellano and Bover (1995) and Blundell and Bond (1998).

\section{Appendix}

Table A. Distribution of regions by economic area

\begin{tabular}{|c|c|c|c|c|c|}
\hline & States & & Prefectures & & Countries \\
\hline \multirow[t]{37}{*}{ The USA } & Alabama & $\underline{\text { Japan }}$ & Aichi & Europe & Andorra \\
\hline & Alaska & & Akita & & Albania \\
\hline & Arizona & & Aomori & & Austria \\
\hline & Arkansas & & Chiba & & Bosnia \\
\hline & California & & Ehime & & Belgium \\
\hline & Colorado & & Fukui & & Bulgaria \\
\hline & Connecticut & & Fukuoka & & Belarus \\
\hline & Delaware & & Fukushima & & Switzerland \\
\hline & District of Colombia & & Gifu & & Cyprus \\
\hline & Florida & & Gunma & & Czech Republic \\
\hline & Georgia & & Hiroshima & & Germany \\
\hline & Hawaii & & Hokkaido & & Denmark \\
\hline & Idaho & & Hycgo & & Estonia \\
\hline & Illinois & & Ibaraki & & Spain \\
\hline & Indiana & & Ishikawa & & Finland \\
\hline & Iowa & & Iwate & & France \\
\hline & Kansas & & Kagawa & & Gibraltar \\
\hline & Kentucky & & Kagoshima & & Greece \\
\hline & Louisiana & & Kanagawa & & Croatia \\
\hline & Maine & & Kochi & & Hungary \\
\hline & Maryland & & Kumamoto & & Ireland \\
\hline & Massachusetts & & Kyoto & & Italy \\
\hline & Michigan & & Mie & & Liechtenstein \\
\hline & Minnesota & & Miyagi & & Lithuania \\
\hline & Mississippi & & Miyazaki & & Luxembourg \\
\hline & Missouri & & Nagano & & Latvia \\
\hline & Montana & & Naoasaki & & Marocco \\
\hline & Nebraska & & Nara & & Moldova \\
\hline & Nevada & & Niigata & & Malta \\
\hline & New Hampshire & & Oita & & Netherlands \\
\hline & New Jersey & & Okayama & & Norway \\
\hline & New Mexico & & Okinawa & & Poland \\
\hline & New York & & Osaka & & Portugal \\
\hline & North Carolina & & Saga & & Romania \\
\hline & North Dakota & & Saitama & & Russian Federation \\
\hline & Ohio & & Shiga & & Sweden \\
\hline & Oklahoma & & Shimane & & Slovenia \\
\hline
\end{tabular}




\begin{tabular}{lll}
\hline Oregon & Shizuoka & Slovakia \\
Pennsylvania & Tochigi & San Marino \\
Rhode Island & Tokushima & Ukaraine \\
South Carolina & Tokyo & United Kingdom \\
South Dakota & Tottori & \\
Tennessee & Toyama & \\
Texas & Wakayama & Yamagata \\
Utah & Yamaguchi & Yamanashi \\
Vermont & & \\
Virginia & & \\
Washington & & \\
West Virginia & & \\
Wisconsin & & \\
\hline
\end{tabular}

\section{Copyrights}

Copyright for this article is retained by the author(s), with first publication rights granted to the journal.

This is an open-access article distributed under the terms and conditions of the Creative Commons Attribution license (http://creativecommons.org/licenses/by/4.0/). 